\title{
Strategi Menaikan Kinerja Guru dalam Online Learning di Era Social Distancing
}

\author{
Andi Sulistiadi \\ Universitas Pelita Harapan \\ andisulistiadi.edu@gmail.com \\ Otto Berman Sihite \\ Universitas Pelita Harapan \\ ottosihite@yahoo.com \\ Virza Utama Alamsyah \\ Universitas Pelita Harapan \\ virzautama@outlook.com
}

\begin{abstract}
The Covid-19 pandemic has a profound impact on the world of education. Online learning (KBM) is a process that must be done. This study aimed to prove a number of HR variables that affects the teachers' performance in the online learning era. In this era, it is believed that the role of teachers as a children educator even the face-to-face is irreplaceable by these digital tools. It turns out that the teacher who performs well is not merely motivated by payroll and bonuses, but there are other aspects that determine the good performance. This study was conducted at Pelita Harapan Bangsa Tegal. The population was 57 teachers and data collection techniques used in this study by distributing questionnaire, and the data were analyze with Smart PLS version 3.0. The result showed that HR variable consisting of Work discipline, Organization commitment and the Work Environment that positively influences teacher performance. HR Strategies have positive effects such as: disciplining in all levels, expressed and fulfilled organizational commitment, as well as work environment that is designed as comfortable as possible for teachers to improve their performance.
\end{abstract}

Keywords: Work Discipline, Organization Commitment, Work Environment, Performance

\section{Article Info}

\section{PENDAHULUAN}

Pandemik Covid-19 mengharuskan segala kegiatan dilakukan dari rumah untuk menghindari penularan dari virus ini. Segala aspek terdampak untuk mengikuti anjuran pemerintah untuk tidak berinteraksi dengan sosial. Demikian pula dengan kegiatan belajar mengajar (KBM). Termasuk kegiatan KBM tingkat PAUD yang mengharuskan para guru lebih kreatif dan berinisiatif untuk menjaga ikatan antara guru dan murid melalui KBM online dengan memanfaatkan chanel dan medsos dunia maya yang ada. Hasil dari KBM online ini menunjukan bahwa seorang guru yang memiliki kinerja baik diprediksi tidak hanya termotivasi oleh faktor penggajian dan 
bonus saja namun melainkan dari disiplin yang dimilikinya, kesesuaian komitmen yayasan terhadap janji yang tidak meleset serta lingkunga kerja yang tertata baik dan nyaman. Guru merupakan ujung tombak dari keberhasilan KBM online ini. Karena meskipun dilakukan secara jarak jauh, peranan guru tetap menjadi tokoh utama dalam proses kegiatan belajar mengajar baik online maupun offline.

Seperti yang diuraikan diatas guru merupakan salah satu dari sumber daya manusia yang berakal, berperasaan, berkeingin, berkemampuan, memiliki ketrampilan, dikaruniakan pengetahuan, memiliki dorongan, memiliki daya, dan mampu menciptakan karya. Satu- satunya sumber yang memiliki aspek rasa, karsa, dan ratio. keseluruhan potensi sumber daya manusia diasumsikan mampu berpengaruh terhadap upaya organisasi dalam pencapaian tujuannya. Walaupun ilmu teknologi maju dan berkembang dengan pesat, berkembangnya informasi, tersedianya modal dan memadainya bahan, akan tetapi dengan ketiadaan sumber daya manusia maka akan sulit bagi organisasi untuk mencapai tujuannya (Faustino Cardoso Gomes 2002:2). Melihat perkembangan era digital yang cukup berpengaruh di dunia Pendidikan termasuk bagi para pendidik, tentunya memberikan sebuah fenomena bagi kinerja guru. Dimana sebelum adanya era digital, peran guru adalah satusatunya saluran dalam proses penyampai pengetahuan bahkan pendampingan spiritual dan karakter akan anak didiknya yang kini sudah tersalurkan oleh media digital yang merupakan hasil dari perkembangan teknologi. Hal ini mengakibatkan perilaku guru dalam menunaikan tugasnya dinilai menurun, bahkan dengan adanya peran digital sebagai subtitusi peran guru, kinerja guru kerap dinilai menurun.Namun tentunya asumsi tersebut belum dapat dipercayai sebagai suatu kebenaran, harus diadakan sebuah Analisa yang menyatakan bahwa kinerja guru sebenarnya tidak terganggu di era digital sekarang ini.
Maka dari itu, penulis memilih untuk melihat dari sudut pandang manajemen sumber daya manusia untuk mengetahui kinerja guru dari kedisiplinan, komitmen yayasan dan lingkungan sekolah. Tempat penelitian ini diadakan di Sekolah Pelita Harapan Tegal yang merupakan sekolah swasta yang berbasis Pendidikan holistic nasional plus. Selaras dengan cara pandang dan upaya yayasan yang mengharapkan terjadinya peningkatan kinerja baik atas guru-guru Pelita Harapan Bangsa maka berdasarkan latar belakang diatas, perumusan masalah dalam penelitian ini adalah Apakah Disiplin kerja berpengaruh terhadap kinerja guru Pelita Harapan Bangsa Tegal, Apakah Komitmen yayasan berpengaruh terhadap kinerja guru Pelita Harapan Bangsa Tegal dan Apakah Lingkungan sekolah berpengaruh terhadap kinerja guru Pelita Harapan Bangsa Tegal.

\section{METODE PENELITIAN}

Metode analisis data yang digunakan dalam penelitian ini adalah model Persamaan Struktural Partial Least Square (SEM-PLS). Penggunaan SEM memiliki keuntungan untuk dapat menguji model penelitian yang kompleks secara bersamaan dan dapat menganalisis variabel yang tidak dapat diukur secara langsung dan memperhitungkan kesalahan mereka (Sholihin, 2013). Dari keseluruhan tujuan penelitian ini adalah bersifat eksplanatori atau memperluas teori yang ada, sehingga analisis SEM yang digunakan adalah SEM-PLS. Ada dua validitas yang digunakan dalam SEM, yaitu validitas konvergen dan diskriminan. Suatu indikator dapat lulus uji validitas konvergen jika nilai faktor pemuatan harus lebih dari 0,7 untuk penelitian konfirmasi, dan nilai faktor pemuatan antara 0,6-0,7 untuk penelitian eksplorasi masih dapat diterima dan Average Variance Extracted (AVE) harus lebih besar dari 0,5 (Ghazali, 2015). Adapun untuk melewati tes validitas, indikator harus memiliki nilai pemuatan yang lebih besar untuk konstruk 
yang diukur bila dibandingkan dengan memuatnya ke konstruk lain (Sholihin, 2013). Sedangkan pengujian reliabilitas dilakukan dengan dua cara, yaitu cronbach's alpha dan composite reliability. Berdasarkan hasil penelitian - penelitian terdahulu dan didukung oleh teori-teori yang telah dikemukakan berikut ini adalah kerangka konsep penelitian dalam diagram di bawah ini :

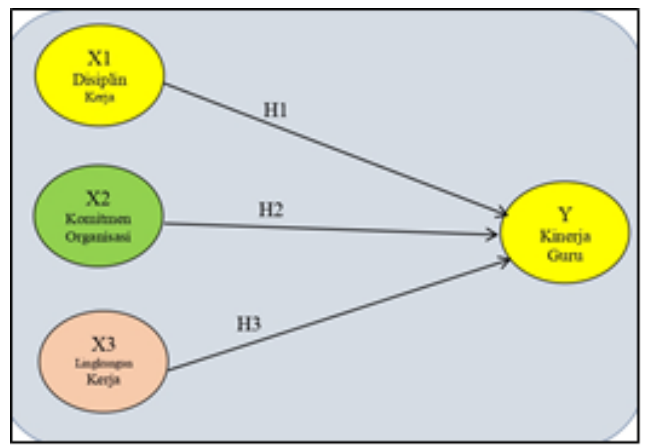

Berdasarkan model hipotesis penelitian yang telah dibuat diatas maka dirumuskan hipotesis-hipotesis penelitian ini sebagai berikut :
1. Hipotesis 1 : Disiplin kerja memiliki rpengaruh positif terhadap kinerja guru

2. Hipotesis 2 : Komitmen Yayasan memiliki pengaruh positif terhadap kinerja guru.

3. Hipotesis 3 : Lingkungan Sekolah berpengaruh signifikan dan positif terhadap kinerja guru.

Berdasarkan hipotesis yang diajukan, maka variabel-variabel yang akan digunakan dalam penelitian ini dibagi atas :

1. Variabel Terikat (Dependent), yaitu variabel yang nilainya dipengaruhi oleh variabel bebas. Dalam penelitian ini yang menjadi variabel terikat adalah kinerja (Y).

2. Variabel Bebas (Independent) adalah variabel yang dapat mempengaruhi perubahan dalam variabel terikat dan mempunyai hubungan yang positif maupun negatif bagi variabel Y. Dalam penelitian ini yang menjadi variabel bebas ada 3 variabel yaitu disiplin kerja (X1), komitmen organisasi (X2), dan lingkungan kerja (X3).

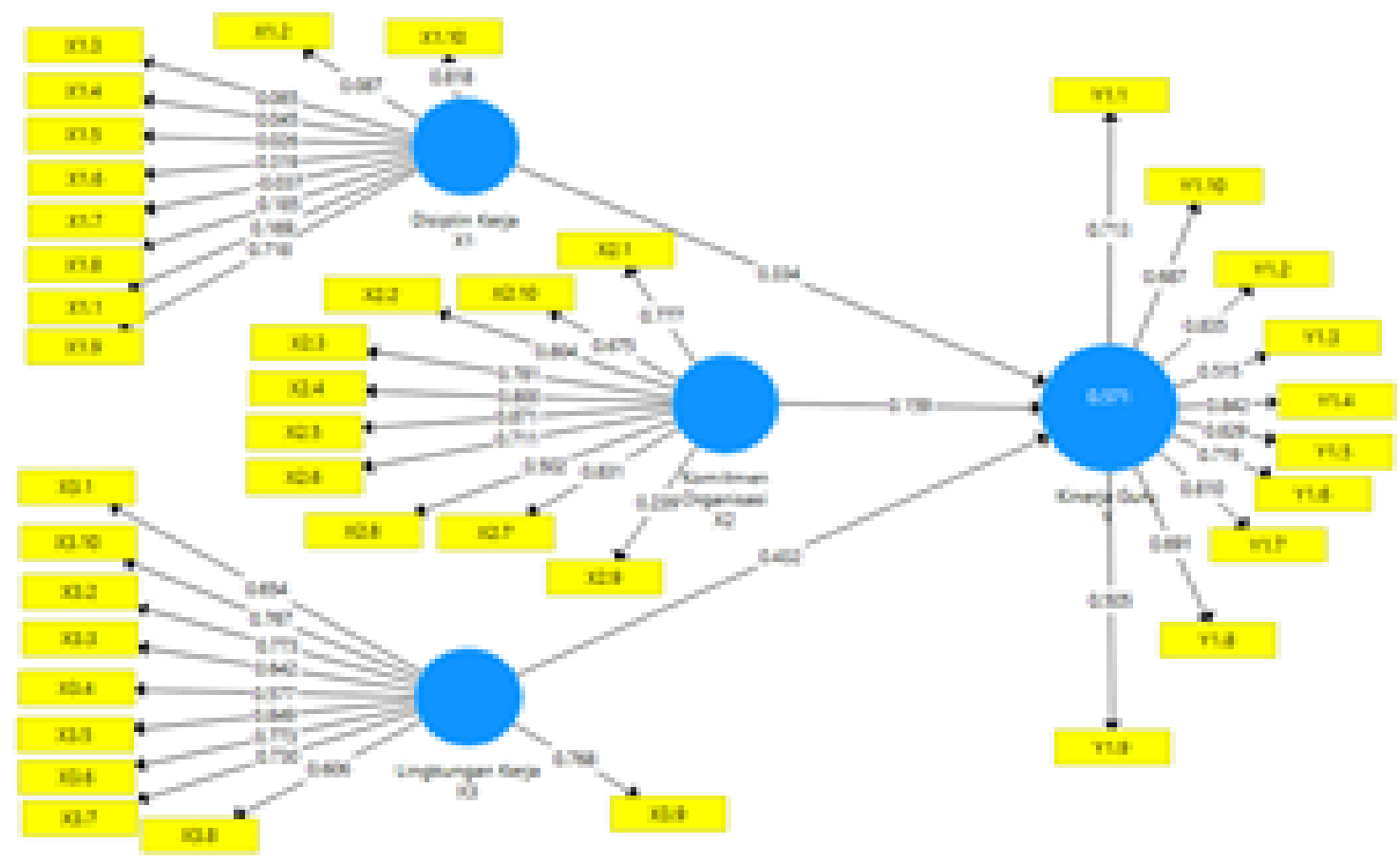

Penelitian ini dilaksanakan di Sekolah Pelita Harapan Bangsa Tegal (PHB) sebuah sekolah berjenjang PAUD-SD \& SMP dibawah naungan Yayasan Tunas Harapan di kota
Tegal dan sebagai subjek dari penelitian ini adalah guru kolah PHB. Objek dari penelitian ini adalah disiplin kerja, komitmen yayasan, lingkungan sekolah dan dampaknya terhadap 
kinerja guru. Dalam melakukan penelitian ini, kuesioner terstruktur sepenuhnya digunakan sebagai instrumen untuk mengumpulkan informasi dari responden. Ini terdiri dari pertanyaan pilihan ganda tertutup dan pertanyaan skala likert yang memungkinkan responden untuk menyatakan tingkat persetujuan mereka dan memilih jawaban terbaik yang paling cocok untuk mereka. Pertanyaan skala Likert untuk penelitian ini menggunakan tujuh poin tanggapan. Item dalam kuesioner dikembangkan menggunakan skala likert 7 poin, yang merupakan tipe interval dari kumpulan data (Sarstedt \& Mooi, 2019). Argumen oleh mereka, skala likert 7 poin dapat dianggap sebagai skala likert karena sudah memenuhi asumsi data regresi OLS. Sementara itu, skala likert 5 poin akan membentuk skala ordinal.

Populasi dalam penelitian ini adalah guru sekolah PHB yang berjumlah 57 orang dan penentuan jumlah sample menggunakan rumus Slovin dengan derajat kepercayaan sebesar 95\%. Adapun teknik pengambilan sampel yang digunakan adalah menggunakan simple random sampling dimana berdasarkan pengundian nomor induk karyawan diambil secara acak sebanyak 57 orang. Analisis pada penelitian ini menggunakan metode analisis data SEM dengan menggunakan software Smart PLS versi 3.0.

\section{HASIL PENELITIAN DAN PEMBAHASAN \\ Hasil Penelitian}

Penggunaan Smart PLS versi 3.01 dengan membuat model penelitian yang menghubungkan antara variabel indpendent dengan variabel dependen. Selanjutnya data qyuisioner dimasukan ke dalam software Smart PLS versi 3.0 untuk kemudian diolah dengan menampilkan diagram estimasi.

Gambar diagram tersebut menunjukan indikator-indikator variable $\mathrm{X}$ memiliki hubungan yang mampu mempengaruhi Kinerja 50
Akumulasi dari perhitungan diagram menyatakan bahwa indikator X1 paling rendah adalah X15 $(0,026)$ sedangkan yang tertinggi adalah X10 $(0,818)$. Sedangkan indikator X2 paling rendah adalah X29 $(0,239)$ dan yang tertinggi adalah $\mathrm{X} 25(0,871)$. Indikator $\mathrm{X} 3$ yang terendah adalah X34 $(0,577)$ dan yang tertiggi adalah X35 (0,849). Sementara Indikator dependen $\mathrm{Y}$ terpengaruh rendah adalah Y19 $(0,505)$ dan yang tertinggi adalah Y14 $(0,842)$.

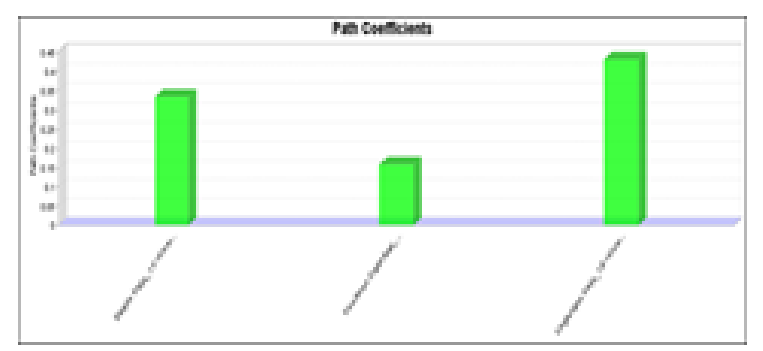

Gambar 3. Diagram path Coefficients

Untuk selanjutnya berdasarkan gambar diagram bar path Coefficients dapat kita Analisa bahwa adanya jalur path coefficient antara ketiga variable independent terhadap variable dependen. Dapat kita lihat bahwa ketiga cariabel berpengaruh positif terhadapa variable $\mathrm{Y}$, sedangkan diantara ketiga variable $\mathrm{x}$, yang tertinggi pengaruhnya terhadapa variable $\mathrm{Y}$ adalah variable $\mathrm{X} 3$.

Tabel Matrix Path Coefficients

\begin{tabular}{|c|c|c|c|}
\hline$\varliminf_{0}$ & Tanatle & $\begin{array}{l}\text { Knarija } \\
\text { Gurn }\end{array}$ & Keternezn \\
\hline 1 & Displin Keja & 0,334 & Sigifilbn \\
\hline 2 & Kouitum Organissi & 0,199 & Signiflen \\
\hline 3 & Linghinzan Kerjo & 0,432 & Signifilen \\
\hline
\end{tabular}

Pengujian mengunakan Smart PLS versi 3.0 membuktikan bahwa disiplin kerja, komitmen yayasan, dan lingkungan sekolah secara simultan memberikan pengaruh positif terhadap kinerja guru Pelita Harapan Tegal. Uji data menunjukan terdapat penyatan yang konsisten yang sejalan dengan penelitian Abdillah (2011) yang membuktikan bahwa disiplin guru memiliki pengaruh positif 
terhadap kinerja guru. Hasil uji hipotesis menunjukkan bahwa disiplin berpengaruh signifikan terhadap kinerja guru.

Pengujian mengunakan Smart PLS versi 3.0 membuktikan bahwa disiplin kerja, komitmen yayasan, dan lingkungan sekolah secara simultan memberikan pengaruh positif terhadap kinerja guru Pelita Harapan Tegal. Uji data menunjukan terdapat penyatan yang konsisten yang sejalan dengan penelitian Abdillah (2011) yang membuktikan bahwa disiplin guru memiliki pengaruh positif terhadap kinerja guru. Hasil uji hipotesis menunjukkan bahwa disiplin berpengaruh signifikan terhadap kinerja guru.

Hasil uji hipotesis menunjukkan bahwa disiplin kerja berpengaruh positif cukup signifikan terhadap kinerja guru. Hasil ini membuktikan bahwa kedisiplinan berpengaruh positif disetiap perubahan nya terhadap kinerja guru. Hasil perhitungan menunjukan sebesar 33\% pengaruh dari displin terhadap kinerja guru. Nilai yang cukup besar pengaruhnya. Dalam hal ini kinerja yang berpengaruh adalah performa kedisiplinan waktu kedatangan dan pulang kerja, kepatuhan guru terhadap penggunaan perangkat canggih sebagai penunjang kebutuhan mengajarnya, ketepatan materi pelahjaran yang disampaikan kepada murid sesuai dengan reancan pembelajaran harian dan mingguan guru yang tentunya disesuaikan dengan buku pelajaran. Kedisiplinan juga dilihat dari ketepatan guru menyeasaikan tugas evaluasi dan lporan lapangannya.

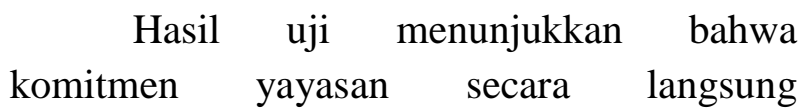
berpengaruh poitif namun tidak begitu signifikan terhadap kinerja guru Pelita Harapan Bangsa Tegal. Hal ini membuktikan bahwa adanya kesesuaian keinginan guru untuk bekerja sebaik-baiknya, peranan yayasan yang mampu menggenapi setiap apa yang dijanjikan dan disepakati antara yayasan dan guru secara konsisten. Seperti komitmen guru yang tidak pernah terlambat akan mendapatkan bonus jalan-jalan sebagai tanda apresiasi yang direalisasikan sesuai waktu dan tempat yang dijanjikan. Dan juga kesesuaian kompensasi yang diberikan seperti THR yang diberikan tepat waktu dengan jumlah nominal yang disesuaikan dengan komitmen awal. Selain itu komitmen yayasan mampu meningkatkan kinerja guru yang dipandang dari semangat dan antusias guru dalam menyelesaikan setiap tugasnya masing-masing dengan terpenuhinya kebutuhan dan keperluan pendukung mengajar, seperti ketersediaannya alat tulis kantor disetiap pengajuan yang dilakukan oleh guru, juga ketersediaanya alat peraga yang sudah diajukan oleh guru sesuai degan jalur birokrasi dan tenggang waktu yang berlaku.

Hasil uji hipotesis menunjukan bahwa lingkungan sekolah berpengaruh positif dan signifikan terhadap kinerja guru. Hal ini menunjukkan bahwa lingkungan sekolah yang dilihat dari kelengkapan fasilitas dan kekinian perangkat pendukung yang diperlukan guru. Guru merasakan nyaman dengan keberadaan barang-barang baru di kelas yang mampu membantu mereka untuk menyelesaikan tugas hariannya, seperti ketersediaan koneksi internet dengan kecepatan yang baik, lalu perangkan gadget yang terkini dengan teknologi terbaru, fasilitas Air Conditioner yang mampu menghadirkan suasana sejuk di ruangan, bahkan sampai dengan warna dinding dan hiasanya yang membuat guru meras betah dan nyaman berada di seskolah. Selain lingkungan sekolah yang berupa fisik, didapati kebutuhan interaksi antara guru juga mampu mempengaruhi kinerjanya. Apalagi dengan tugas guru yang terbentuk dalam sebuak pekerjaan berkelompok yang menunjukan bahwa kenyamanan dalam teamwork bagian dari penentu kinerja para guru.

Pengaruh Disiplin Kerja Terhadap Kinerja Guru Pelita Harapan Bangsa Tegal

Pengaruh disisplin kerja terhadap kinerja guru menunjukan bahwa adanya 
hubungan positif yang saling mempengaruhi satu dengan yang lain. Peraturan dari sekolah dinilai tidak bertele-tele dan memilik nilai kewajaran untuk dijalankan. Sebagian besar guru sudah menyatakan dirinya untuk mematuhi pendisiplinan waktu dan juga setiap tata aturan yang berlaku di sekolah. Para guru dianggap sudah memiliki kesadaran untuk memenuhi proses kedisiplinan kerja mereka dan berhasrat untuk menjaga nama baik dirinya sendiri sebagai dan guru dan juga sebagau duta dari sekolahnya. Dari hasil analisis regresi menunjukkan bahwa variabel disiplin kerja secara positif berpengaruh terhadap kinerja guru yang sejalan dengan penelitian sebelumya oleh Ivonne A.S Sajangbati (2013)

Para guru merasakan bukti nyata dari komitmen yayasan disetiap kesepakatan yang sudah diberikan pada mereka. Di setiap kahir tahun, yayasan meberikan apressiasi rewards kepada setiap guru-guru yang berprestasi di kancah internal maupun eksternal. Hal ini membuat rasa memiliki dn kebanggan akan sekolah terhadap para gur, sehingga pada akhirnya kinerja guru semakin baik dan yayasan memiliki guru-guru yang juga berkomitmen penuh terhadap sekolah. Hal ini selaras dengan penelitian sebelumnya yang dilakukan oleh Edy Sujana (2012) yang menunjukan bahwa komitmen organisasi atau dalam hal ini yayasan mampu mempengaruhi secara positif kinerja guru.

Pengaruh lingkungan sekolah terhadap kinerja guru dinilai signifikan positif. Setiap perubahan yang terjadi di lingkungan sekolah membuat guru semakin antusias untuk melakukan tanggung jawabnya. Lingkungan kerja fisik dan non fisik keduanya memiliki indikasi yang mempengaruhi kinerja guru. Dimana guru dinilai memiliki perasaan senang terhadap setiap perubahan postif lingkungan sekolah yang berupa fisik . Ditambah dengan lingkungan sekolah non fisik yang semakin memperkuat perasaan senang dan kondisi kerja yang memiliki energy positif. Guru mampu 52 menunjukan hasil kerjanya dengan baik secara disadari maupun tidak dikarenakan perubahanperubahan fasilitas terkini dan juga suasan hubungan antar guru yang dibangun dengan kekeluargaan dan kerjasama yang solid.

Berdasarkan situasi tadi, dapat disimpulkan bahwa dalam lingkungan kerja fisik dan non fisik pada guru disini dinilai baik, itu berarti para guru tidak memiliki masalah akan perilaku antar sesame guru, mereka dinilai mampu untuk menerapkan sopan santun yang baik antar sesama dan juga atasan. Hasil kajian ini sejalan dengan penelitian yang dilakukan oleh Aurelia Potu (2013) yang menunjukkan bahwa variabel lingkungan sekolah memilik hubungan positif signifikan berpengaruh terhadap kinerja guru/karyawan. Terbukti, bahwa para guru lebih kreatif dan berinisiatif untuk menjaga ikatan antara guru dan murid melalui KBM online dengan memanfaatkan chanel dan medsos dunia maya yang ada karena sudah mmiliki dispilin kerja yang mandiri, kesesuaian komitmen yayasan dari setiap dukungan yang suportif menjadi guru semakin bersemanga sedangkan lingkunga kerja yang tertata baik dan nyaman bahkan semakin diperlengkapi membuat guru semakin bersemnagat untuk melakukan proses KBM. Sekali lagi, Guru merupakan ujung tombak dari keberhasilan KBM online ini. Peranan guru tetap menjadi tokoh utama dalam proses kegiatan belajar mengajar baik online maupun offline.

\section{SIMPULAN DAN SARAN \\ Simpulan}

Berikut ini adalah hasil dari kesimpulan penelitian Strategi Manajemen SDM untuk meningkatkan kinerja guru di era online learning,

1. Hasil dari olah data menunjukan adanya signifikansi sebesar 0,43 atau $43 \%$ antara lingkungan sekolah berpengaruh positif dan signifikan terhadap kinerja Guru Pelita Harapan Bangsa Tegal, yang bearti semakin 
lingkungan sekolah baik fisik maupun non fisik diperlengkapi, mampu meningkatkan kinerja guru juga.

2. Disiplin kerja dengan nilai signifikansi sebesar 0,334 atau 30\% dinilai berpengaruh positif dan signifikan terhadap kinerja Guru Pelita Harapan Bangsa Tegal, yang berarti peningkatan disiplin kerja akan mempengaruhi peningkatan kinerja guru.

3. Sedangkan komitmen yayasan dengan nilai signifikansi sebesar 0,159 atau $15 \%$. Yang tentunya berpengaruh positif dan signifikan terhadap kinerja Guru Pelita Harapan Bangsa Tegal, yang berarti setiap peningkatan komitmen yayasan akan mempengaruhi kinerja guru.

\section{Saran}

Berikut ini adalah beberapa saran yang penulis sampaikan mengenai strategi manajemen SDM untuk meningkatkan kinerja guru di era online laerning

1. Kinerja guru yang baik ditemukan di sekolah Pelita Harapan Bangsa yang pertama diakibatkan dengan adanya peningkatan mutu dari fasilitas sekolah yang memperlengkapi tugas kerja guru dan juga factor lingkungan kerja non fisik yang mampu menimbulkan rasa senang dan semangat bagi para guru untuk menajalankan tugasnya dengan penuh antusias. Hal ini dinilai sangat penting karena guru adalah sebagai sosok pendidik yang akan ditiru oleh murid-muridnya, dan api semangat dan sukacita yang dimiliki guru akan tersampaikan kepada anak didiknya. Walaupun di era digital ini, dengan adanya fasilitas online learning, tetap saja peranan guru termasuk emosi yang tersirat dalam proses kegiatan belajar mengajarnya perlu untuk dijaga dan dikembangkan melalui penyediaan tata lingkungan sekolah yang baik dan bersifat kekinian serta jalinan suasana kerjasama antara guru yang dibuat senyaman mungkin dengan asas hubungan kekeluargaan.
2. Penelitin memberikan hasil yang baik bahwa komitmen yayasan mempunyai pengaruh positif terhadap kinerja guru Pelita Harapan Bangsa Tegal. Ada beberapa komitmen organisasi yang harus dievalusi yang ada dalam sekolah ini agar dapat dikategorikan golongan baik dengan dengan cara mengukur indikator-indikatornya. Ditemukan indikator rata-rata paling rendah yaitu pemberian apresiasi, Yayasan dinilai masih terkesan acuh dan tidak konsisten. Hal tersebut harus diatasi karena pemberian apresiasi secara tepat waktu dan konsisten adalah sebuah janji yang tentunya diyakini harus ditepati. Dalam mengatasi masalah tersebut yayasan harus lebih meningkatkan penjadwalan pemberian apresiasi dan kompesasi derta reward tepat pada waktunya dan konsisten.

3. Disiplin kerja guru juga sangat penting, terutama disiplin yang berjalan atas dasar kesadaran guru dari hatinya yang terdalam. Ini menunjukan bahwa peraturan-paraturan sekolah tidak menjadi beban dan penghalang bagi para guru. Semua guru menjalankan tugasnya dengan kesadaran bahkan karena kebanggaannya terhadap sekolah. Guru menunaikan segala tugasnya dengan kewajiban yang baik atas dasar rasa memiliki dan juga integritas yang ditunjukan sebagai pembelajaran bagi anak didiknya. Hal ini dinilai sangat baik bagi proses operasional sekolah. Namun tidak hanya guru saja yang harus memiliki kesadaran akan disiplin kerja ini, para jajaran direktorat dan manjerial yayasn pun sebaiknya memiliki nilai integritas yang sama untuk menerapkan disiplin kerja ini sebagai budaya organisasi secara keseluruhan. Pendisiplinan yang berlaku untuk seluruh jajaran ini dinilai akan menimbulkan dampak baik, dikarenakan guru akan melihat sendiri bahwa pimpinan mereka menunjukan komitmen terhadap pentingnya disiplin kerja di sekolah tersebut. 


\section{DAFTAR PUSTAKA}

Abdillah,Arief Chaidir \& Farid Wajdi.2011.Pengaruh

Kepemimpinan,StressKerja,Disiplin

Kerja,Dan Kompensasi Dengan Kinerja

Pegawai.Program Pasca Sarjana

Magister Manajemen Universitas

Muhammadiyah Surakarta.

Agusta,Leonando \& Eddy Madiono Sutanto.2013.Pengaruh Pelatihan \&

Motivasi Kerja Terhadap Kinerja Karyawan CV.Haragon

Surabaya.Program Studi

Manajemen,Universitas Kristen Petra.

Alex S Nitisemito, (2008), Manajemen Personalia (Manajemen Sumber Daya Manusia, Edisi Kelima, Cetakan Keempat belas, Ghalia Indonesia, Jakarta.

Anggraeni,Nenny.2011.Pengaruh Kemampuan dan Motivasi Terhadap Kinerja Pegawai Pada Sekolah Tinggi Seni Indonesia (SSTI) Bandung.Dosen Manajemen Produksi Jurusan Karawitan Sekolah Tinggi Seni Indonesia (STSI) Bandung.

Arfan,I Lubis.2010.Akuntansi Keperilakuan.Salemba empat:Jakarta.

Arianto,Dwi Agung Nugroho.2013.Pengaruh Kedisiplinan,Lingkungan Kerja, dan Budaya Kerja Terhadap Kinerja Tenaga Pengajar.Universitas Islam Nahdatul Ulama Jepara,Indonesia.

Brahmasari,Ida Ayu \& Peniel Siregar.2009.Pengaruh Budaya Organisasi,Kepemimpinan Situasional \& Pola Komunikasi Terhadap Disiplin Kerja \& Kinerja Karyawan Pada PT.Centra Proteinaprima Tbk.Universitas 17 Agustus 1945 Surabaya \& Plant GM, PT.Centra Proteinaprima Tbk.
Dhermawan,Anak Agung Ngurah Bagus dkk.2012.Pengaruh Motivasi,Lingkungan

Kerja,Kompetensi,Dan Kompensasi Terhadap Kepuasan Kerja Dan Kinerja Pegawai di Lingkungan Kantor Dinas Pekerjaan Umum Provinsi Bali.Fakultas Ekonomi Universitas Udayana.

Ghozali,Imam.2006.Aplikasi

Analisis

Multivariate Program SPSS. Badan

Penerbit

Universitas

Diponegoro:Semarang.

Ghozali, I. (2008). Structural Equation Modeling, Metode Alternatif dengan Partial Least Square. Semarang. Badan Penerbit Undip.

Gomes,Faustino Cardoso.2002.Manajemen

Sumber Daya

Manusia.Andi:Yogyakarta.

Hakim, Abdul. 2006.Analisis Pengaruh Motivasi, Komitmen Organisasi Dan Iklim Organisasi Terhadap Kinerja Pegawai Pada Dinas Perhubungan Dan Telekomunikasi Provinsi Jawa Tengah.Jurnal Riset Dan Bisnis Indonesia (JRBI Vol. 2. No.2 Juli 165180).Unisuls Semarang.

Handoko,T.Hani.2008.Manajemen Personalia $\&$ Sumber Daya Manusia edisi 2.BP FEYogyakarta:Yogyakarta.

Hasibuan,Malayu S.P.2005.Manajemen Sumber Daya Manusia.PT.Bumi Aksara: Jakarta. Mahmudi.2013. Manajemen Kinerja Sector Public.UPP STIM YKPN:Yogyakarta.

Manaf,Indra Gunawan dkk.2015.Pengaruh Lingkungan Kerja dan Disiplin Terhadap Motivasi Kerja Pegawai Implikasinya Terhadap Kinerja Sekretariat Kecamatan Dalam Kabupaten Simelue.Magister Manajemen Program Pascasarjana. 
Rivai, \&Sagala. (2011). Manajemen Sumber

Daya Manusia untuk Perusahaan. Jakarta : PT. Rajagrafindo Persada.

Robbins SP, dan Judge. (2002). Perilaku Organisasi Buku 2, Jakarta : Salemba.

Sarwono, J., \& Narimawati, U. (2015). Membuat Skripsi, Tesis dan Disertasi dengan Partial Least Square SEM (PLS-SEM). Yogyakarta: Penerbit ANDI.

Siagian \& Sondang P. (2002). Teori dan Praktek Kepemimpinan, Bumi
Aksara.Jakarta. Sedarmayanti. (2009). Sumber Daya Manusia dan Produktivitas Kerja. Bandung: Mandar Maju. Sugiyono. (2010). Metode Pendekatan Kuantitatif, Kualitatif dan R\&D. Bandung: Alfabeta.

Sugiyono. (2017). Metode Penelitian Kuantitatif, Kualitatif, dan $\mathrm{R}$ \& D.Bandung: Alfabeta.

Wibowo. (2007). Manajemen Kinerja. PT. Raja Grafindo Persada. Jakarta. 